\title{
Microbial Contaminants and Their Control Methods: A Review with Reference to Potato Tissue Culture
}

\author{
Lemma Tessema* Ebrahim Seid Zewditu Moges \\ Ethiopian Institute of Agricultural Research, Holetta Agricultural Research Centre, \\ P.O.Box 2003, Addis Ababa, Ethiopia
}

\begin{abstract}
No cell or tissue culture problem is as universal as that of culture loss due to contamination, so that microbial hazards cause drastic economic losses in the plant tissue culture industries. A wide range of microorganisms (filamentous fungi, yeasts, bacteria, virus and viroid) and micro-arthropods (mites and thrips) have been identified as contaminants in plant tissue culture. With this paramount importance of in-vitro culture contaminants, various research work has been conducted from different corners of the world. This review paper compiles such important information to share experiences within a single amassed document. Different research and review articles, proceedings, protocol notes, scientific notes, conference papers, case reports as well as case studies, research communications and technical reports are included in this paper. Hence, this article aimed to review and provide insights about microbial contaminants and their management techniques and thereby to document the possible attempts made by different scholars to mitigate microbial contamination under plant tissue culture. Moreover, the paper skim through the current advancements made on culture loss due to microbes, their control methods and hostile effects on regeneration capability of culture plants.
\end{abstract}

Keywords: Microbial contamination, bacteria, fungi, plant tissue culture, in vitro culture

DOI: $10.7176 / \mathrm{JNSR} / 12-10-01$

Publication date:May $31^{\text {st }} 2021$

\section{Introduction}

Technological advances in biotechnology provide new insights with gaining much attention and open new options for collection, preservation, multiplication and exchange of plant genetic resources in the form of in vitro culture among nations (Cruz-Cruz et al., 2013). Plant tissue culture also ensures rapid multiplication and production of plant material under aseptic conditions for commercial or industrial purpose (Cruz-Cruz et al., 2013; Tegen and Mohammed, 2016; Yadav et al., 2019). Nevertheless, enormous number of microbes are adversely affecting in vitro cultures and poses a threat to plant tissue culture laboratories (Odutayo et al., 2007; Varghese and Joy, 2016).

Culture contaminants may be biological or chemical, seen or unseen, destructive or apparently benign, nonetheless in all cases they harmfully affect both the use of our cultures or the quality of our research (Ryan, 2008; Varghese and Joy, 2016). Microbial hazards in plant tissue culture are associated with pathogens and microbial contaminants (Leifert and Cassells, 2001). A wide range of microorganisms (filamentous fungi, yeasts, bacteria, virus and viroid) and micro-arthropods (mites and thrips) have been identified as contaminants in plant tissue culture (Pype et al., 1997; Leifert and Cassells, 2001; Altan et al., 2010). Contrasting to mycoplasma and bacteria, fungi are eukaryotes and can exist as round or oval bodies (yeasts) that can form chains or clusters, or as long thin filaments or hyphae (Mather and Roberts, 1998). Studies revealed that microbial contamination remains a continuing threat to plant tissue culture for several years although there are techniques that can reduce the consequence of contamination (Varghese and Joy, 2016; Carey et al., 2015).

Bacterial contamination is a major and persistent threat to the establishment and subculture of in vitro plant culture (Liang et al., 2019). Bacterial microorganisms that are latent in-vitro cultures can limit the efficiency of in-vitro methods for the conservation of genetic resources in numerous steps (Izarra et al., 2020). Ten bacterial contaminants (Pseudomonas fluorescens, Escherichia coli, Proteus spp., Micrococcus spp., Streptococcus pneumoniae, Staphylococcus aureus, Bacillus cereus, Bacillus subtilis, Corynebacterium spp. and Erwinia spp.) and eight fungal contaminants (Alternaria tenuis, Aspergillus niger, Aspergillus fumigatus, Cladosporium spp., Saccharomyces spp., Fusarium oxysporum, Rhizopus nigricans and Fusarium culmorum) were isolated from plant explants of cassava, Kenaf, Cowpea and Banana in Southwestern Nigeria which affects the production of tissue culture plantlets (Odutayo et al., 2007). Similarly, nine microbial contaminants containing of five bacterial and four fungi species were isolated from Hibiscus cannabinus and Telfaria occidentalis tissue culture with different level of occurrence and in vitro damage (Odutayo et al., 2004). In the other study by Kidus and Teka (2020) Escherichia, Bacillus and Micrococcus were isolated and identified as the major contaminant bacteria of sugarcane in vitro cultures in Tigray biotechnology laboratory in Ethiopia. Mycoplasmas, the smallest selfreplicating organisms known has the ability to alter their host cultures' cell function and causes chromosomal aberrations and damage (Lincoln and Gabridge, 1998).

To overcome such serious threats, implementing proper contamination remedies based on their 
recommendations and following proper laboratory procedures will also be quite important to reduce contamination induced loses of time, energy, effort and valuable plant materials (Ryan, 2008).

Since from the very beginning to recent advancements, plant biotechnologists and pathologists made marvelous investigations commenced from preliminary studies of microbe isolation, morphological and biochemical characterization, and DNA sequencing and identification to find out solutions for in vitro contaminants, which are threatening the production, multiplication, conservation and distribution of humans common wealth, plant species (Altan et al., 2010; Izarra et al., 2020; Kidus and Teka, 2020). With this paramount importance of invitro culture contaminants various research work has been done from different corners of the world. This review paper compiles such important overview to share experiences. Different research and review articles, proceedings, protocol notes, scientific notes, conference papers, case reports as well as case studies, research communications, technical reports, etc. are reviewed and included in this paper. This article was aimed to review and provide insights about microbial contaminants and their management techniques under plant tissue culture and thereby to document the possible attempts made by different scholars to mitigate microbial contaminants under plant tissue culture.

\section{Importance of plant tissue culture}

According to FAO's estimation, the global food production must increase by $70 \%$ to feed the ever-growing world's population which is projected about 10 billion in the near future by 2050 (FAO, 2017). This cannot be realized without increasing crop productivity and conserving natural resources including the plant genetic materials (Tegen and Mohammed, 2016; FAO/IAEA, 2018). Moreover, humans have a long history of reliance on plants for numerous benefits most likely for foods, shelters, medicines and others (Espinosa-Leal et al., 2018). Hence, modernizing our agriculture is the key area of reducing the challenges of feeding the ever-growing world population because the current trends of agriculture threaten the sustainability of food systems and undermine the world's capacity to meet its food needs (FAO, 2017). Plant biotechnology has, for the last several decades made a significant impact on world agriculture. Plant tissue culture denotes the most promising areas of biotechnology application since its beginning in 1902 by a German physiologist, Haberlandt who attempted to culture isolated single plastid cells from leaves in Knop's salt solution enriched with sucrose and giving an outlook in to the future. Many biotechnological approaches from simple in-vitro multiplication to sophisticated genetic engineering are developed and used as a tool for modern agriculture by researchers (Tegen and Mohammed, 2016; Tazeb, 2017). Advances in invitro systems are readily taken up and exploited in plant improvement schemes including mutation induction, mutation selection and mutant line development (IAEA, 2004; FAO/IAEA, 2018). In vitro methods have been an important part of plant biology and crop breeding since the early 1960s. Plant tissue culture exploits the in-vitro plasticity of plant growth and development. Establishment, multiplication and maintenance of in-vitro plantlets free from bacteria or other contaminants is very important to micro-propagate plants under aseptic conditions (Scortichini and Chiariotti, 1987).

Plant tissue culture technology is used for the production of double haploids, cryopreservation, propagating new plant varieties, conserving rare and endangered plants and to produce secondary metabolites and transgenic plants (IAEA, 2004). Moreover, plant tissue culture could be used as an alternative option for the supply of highquality planting materials for developing countries to solve shortage of quality seed, the most common production bottle neck for vegetatively propagated crops like potato (IAEA, 2004; Tessema and Dagne, 2018). Potato tissue culture at Holetta Research Centre, Ethiopia is playing a key role and used as a gear to supply in vitro plantlets to the seed production schemes of aeroponics, sand hydroponics and screen houses (Figure 1) that enhances accelerated quality seed potato supply efficiency by $7.6 \%$ (Tessema et al., 2018). The field of plant tissue culture also widen the scope of producing plantlets which does not set seeds in natural condition (Leelavanthy and Sankar, 2016).

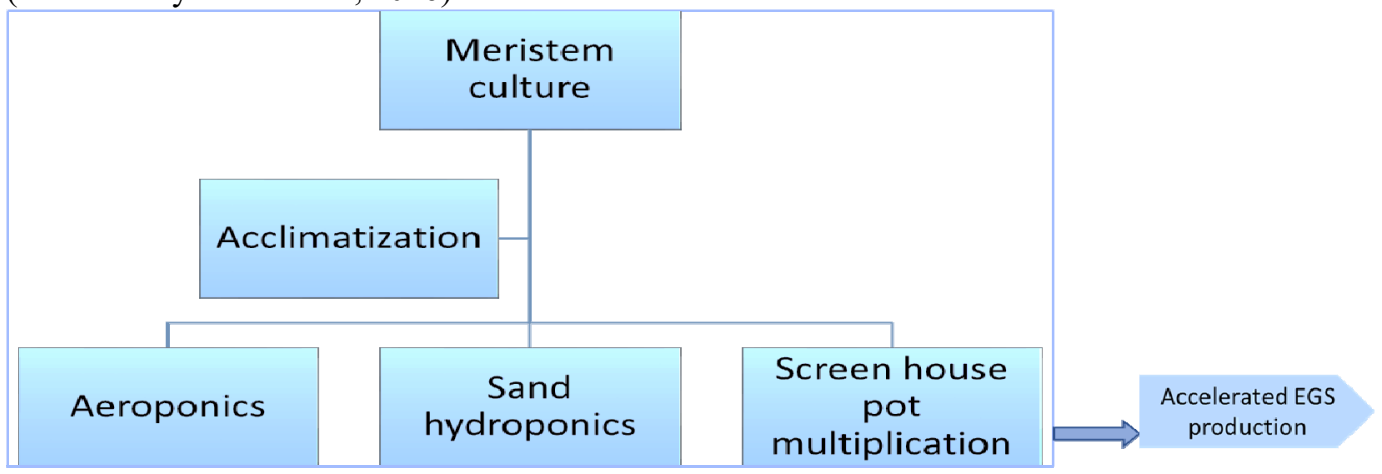

Figure 1: Meristem culture as a source for accelerated early generation seed (EGS) production techniques at Holetta Research Centre (Source: Tessema et al., 2018) 
Many scholars perform in vitro manipulation technology in potato varying from the low-input and widely adopted technology of micropropagation to the complex manipulation of multi-gene biosynthetic pathways through transgenic intervention. Potato is considered as one of a model species for methods such as somatic hybridization due to its in vitro regeneration capacity to overcome the sexual barriers between the cultivated (Solanum tuberosum L.) and wild species (Melchers et al., 1978; Tiwari et al., 2018) and Agrobacteriummediated transformation (Conner et al., 1992; Millam, 2007; Cingel et al., 2010; Chetty et al., 2015). Several improvements have been made for more than two decades with respect to tissue culture, transformation, and regeneration of potato (Bruce and Shoup Rupp, 2019). Plat tissue culture as an important tool for the continuous production of active compounds such as vaccines and pharmaceuticals (Espinosa-Leal et al., 2018).

Root and tuber crops, being propagated vegetatively, are inherently more susceptible to maintenance, increase, as well as dissemination of both systemic and non-systemic diseases than that of sexually reproduced crops which come from true seeds (Bryan, 1983; Tessema et al., 2020). The systemic diseases, like viruses, viroid, bacteria, and mycoplasma pathogens are the most devastating in terms of yield loss for the root and tuber crops (Bryan, 1983). The era of plant tissue culture technology opens a door with plenty of opportunities for plant pathologists to eliminate such yield hindering pathogens and thereby enables to get healthy planting materials.

\subsection{Germ plasm conservation}

Plant germplasm collection and its conservation are an integral part of safeguarding the availability of plant genetic martials for present and future breeding programs of imperative horticultural and agricultural plant crops; preservation of rare and endangered species, and of heritage plants (Johnson, 2002). Potato genetic resources held ex situ are divided in to potato wild relatives (maintained as seed populations) and cultivated varieties which are maintain either in field plantings (where tubers are planted and harvested annually, seed, in vitro/clonal material, or cryopreserved material (Ellis et al., 2020). The method of ex situ conservation of potato germplasm as seed (tubers) is not only labor intensive, time-consuming, cumbersome but also the conserved materials would be lost due to exposure to hazards, pest, diseases and other natural catastrophes. Hence, meristem culture conservation method in the form of cryopreservation has been suggested as a novel approach for potato almost for the last three decades (Bajaj, 1987). Cryopreservation, freezing tissue in liquid nitrogen at $196{ }^{\circ} \mathrm{C}$ has been used for the long-term preservation of intact living cells and tissues (Budd, 2016).

Various cryopreservation protocols have been developed, approved and used for the last decades by different institutions and scientists across the world to conserve the plant genetic martials of different valuable accessions (Plumier, 2019; Wilms et al., 2020). Each crop part to be conserved responds variously for different types of media or preservation protocols. The study of Vollmer et al. (2019) realized that, cryopreserved potato shoot tips showed genotype-specific response to sucrose concentration in rewarming solution (RS).

Recognizing the threat of genetic erosion in the center of diversity that would happen due to various natural and man-made hazards and the wild relative species exist only in fragile ecosystems of the Andes, the International Potato center (CIP) and its collaborators are collecting and conserving huge number of potato accessions (Hijmans and Spooner, 2001; Vollmer et al 2016). Among the 45 years of existence of the potato genebank the number of cultivated potato accessions peaked at 17,326 accessions. After extensive research involving the identification and removal of duplicates, the active cultivated potato collection now total 4,727 accessions including 4,354 traditional landrace cultivars from 17 countries (mainly from the Andean region) and improved varieties. The entire clonal collection is conserved in vitro and distributed internationally as tissue cultured materials. All the accessions in the collection are maintained and available for use in research, breeding and training by humanity now and into the future (CIP, 2021a).

Together these collections comprise over 11,000 accessions maintained in tissue culture and held in trust under the International Treaty for Plant Genetic resources for food and agriculture. Moreover, the genebank holds additional 4,500 in vitro accessions from the CIP-derived breeding research materials (CIP, 2021b). It is mandatory to conserve and reproduce plants important for food, medicine and other uses to satisfy the evergrowing populations of the world and also in urgent to conserve the agricultural, economical, rare and endangered plant species or families in space wise techniques under safeguarded area (Singh, 2018). The International Potato Centre (CIP) in-vitro preservation unit at Lima Peru, maintains the global in-trust collection of cultivated potato, that could be used for multiple purpose and a common wealth for the international community CIP, 2021b).

\subsection{Embryo culture}

Embryo culture, an in-vitro technique, is referred as embryo rescue technique used to save deterioration of hybrids. Embryo rescue and culture is a technique that has found wide acceptance and utilization (Stewart, 1981). In-vitro cloning or asexual propagation is also reported as one of the most apparent and commonly used features of plant cell and tissue culture technology (Lawrence, 1981; Yadav et al., 2019). The complex 
developmental processes such as organogenesis and somatic embryogenesis that improves the efficiency of regeneration protocols for recalcitrant species could probably be skipped by the application of genomics and transcriptomics under the circumstance of plant tissue culture (Loyola-Vargas and Ochoa-Alejo, 2018; Yadav et al., 2019).

As enabling as well as evolving technology, plant tissue culture technique has been developed and used as a novel tool to assist plant breeders for crop improvement that was impossible through conventional breeding procedures (Tazeb, 2017). The study conducted by Castillo et al. (2016) assessed different culture media (ascorbic acid, L-cysteine and silver nitrate) to prevent browning of anther cultures from wild diploid Solanum species and effective embryogenesis was induced in growth media with silver nitrate $\left(\mathrm{AgNO}^{3}\right)$. The response to embryogenesis among potato cultivars or species was highly varied and some cultivars are superior than others (Asakaviciute et al., 2007). Based on different growth media evaluated for embryo culture, N6 nutrient medium has provided better results $(14.61 \%)$ when compared to MS medium $(8.78 \%)$ in regard to embryos formation and the overall androgenesis process of the anther culture in Snatana cultivar (Aboshama and Atwa, 2019). Millan

\subsection{Haploid and double haploid production}

The modern cultivated potato (Solanum tuberosum L.) is a tetraploid, that has four sets of chromosomes $(2 n=4 x=48)$ instead of the usual two sets that occur in the more normal diploid plants. Which in turn means that the cultivated potato cannot easily be crossed with many wild potatoes, which are mostly diploids. Haploids $(2 n=24)$ of the common tetraploid $(2 n=48)$ potato (Solanum tuberosum L.) provide promising material for offensive many difficulties troubled with the genetics, cytogenetics and breeding of this species (Peloquin et al., 1996). Modern potato varieties are the products of extensive breeding between different cultivar group and wild potato species which consumes almost one and half a decade to release new potato variety through conventional breeding (Spooner et al., 2014; Jansky et al., 2016). The long cycle consumption for potato variety development is the quantitative nature of most important traits, the rapid inbreeding depression, and the low intensity of selection in early generation (Milczarek et al., 2014; Bonierbale et al., 2020). Moreover, the propagation through tubers needs prolonged time due to low multiplication rate and ease of contamination by various pathogens leading to seed degeneration that causes the gradual decomposition of genetic potential of the screening clones and finally the clones perform less than the standard checks being evaluated with and discarded there unless the materials be cleaned and multiplied by meristem culture technique (Aboshama and Atwa, 2019; Azad et al., 2020). All these factors contributed to the delay of potato breeding cycles (Milczarek et al., 2014).

Haploid production reduces the time required to produce the improved cultivar of a specific plant. Haploid and double haploid was produced from Anther culture (Germana, 2011). Breeding programs for most food security crops like potato seek different alternatives to accelerate the production of improved varieties with desirable agronomic traits. Now a days there is a tremendous opportunity to harness recent advances in potato breeding and improvements in these endeavors. As a success story, diploid hybrid breeding is finally making its way for almost more than two decades after discovering a superior gene of the self-incompatibility locus of diploid potatoes (Ghislain and Douches, 2020). The first haploid plant regeneration from anther culture in Solanum commersonii of with induced gametic embryogenesis from wild diploid solanum spp. was reported by Castillo et al. (2016) with important implications in sequencing efforts and potato breeding.

An alternative approach based on the use of haploids $(2 n=2 x=24)$ produced from tetraploid S. tuberosum along with available genomic tools have also provided means to get insights into natural mechanisms that take place within the genetic load and chromosomal architecture of tetraploid potatoes (Ortiz and Mihovilovich, 2020). Haploid extraction from three tetraploid parents were undertaken and $5-10 \% 2 \mathrm{n}$ pollen (pollen with the sporophytic chromosome number) was obtained that was maternally derived through parthenogenesis (Peloquin et al., 1996). An improvement of main agronomic traits of dihaploids with $2 n$ gametes by means of sexual hybridization and anther culture of potato (Solanum tuberosum) was reported by Wang and Ran (2000). The result also suggested that manipulating the ploidy through sexual polyploidization and dihaploid induction by anther culture is an effective method to obtain dihaploid clones with $2 n$ gametes in combination with good tuber yield and tuber appearance in potato (Wang and Ran, 2000). Double haploid plantlets of potato from anther culture were reported by Aboshama and Atwa (2019).

\subsection{Indexing and production of disease-free planting materials}

Pathogen elimination activity is fundamental to guarantee towards conservation and safe exchange of germplasm (Zea et al., 2015; Izarra et al., 2020). The production and supply of disease-free planting materials is a key component to boost product and productivity of any crop that has economic importance, and plant tissue culture enables us to solve this critical problem by eliminating viruses from infected plant sources (Loyola-Vargas and Ochoa-Alejo, 2018). The process of pathogen elimination of potato in CIP's genebank currently used is based on: i) Initial health status testing by serological, molecular and host range; ii) Accessions with viral infection are 
subjected to virus elimination therapy by combining incubation at high temperature (Thermotherapy) with cut and meristem culture and iii) Final health status testing to detect a possible virus infection remaining after virus elimination therapy (Zea et al., 2015).

Elimination of microorganisms from plant cells and tissues that adversely affect in vitro cultures has been reported by several researchers. Out of 2,373 accessions screened from the invitro sweet potato germplasm collection of the International Potato Centre, 240 accessions $(10.1 \%)$ were confirmed to be contaminated with bacteria. Out of which the surviving 191 accessions were processed for bacterial elimination through a combination of morphological and partial 16S rDNA sequencing methods. After 14 months of cleaning the accessions, the plants were truthfully free of bacterial contamination and that the PCR results were accurate in that respect (Izarra et al., 2020). Since in vitro plants genetic resources must be microbe-free for international distribution and use, any microbial presence is considered a contamination and therefore it is mandatory to clean all cultures before any consignment to possess phytosanitary certificates for those materials to be distributed in side or abroad countries (Izarra et al., 2020). In such obligations, indexing our plant material from different pathogens must be the precondition.

Meristem culture, one of an important plant tissue culture applications become and continues a powerful tool for virus elimination from infected plants and has been successfully applied in potato for several years (Al-Taleb et al., 2011; Azad et al., 2020). The production and dissemination of high-quality planting material of crop plants and fruit trees, propagated from vegetative parts, has created new opportunities in global trading, benefited growers, farmers, and nursery owners (IAEA, 2004). The study by Azad et al. (2020) confirmed that the field study of in vitro meristem-derived plantlets was free of potato viruses based on DAS-ELISA detection. The disease indexing of mother plants for freedom from viral, bacterial, and fungal diseases is a normal procedure in the large- scale plant propagation through tissue culture (Schmidt et al., 2004). Unlike conventional plant propagation for most vegetatively propagated crops like potato, the elimination of most viruses that invade potato can be achieved by a combination of apical meristem culture and thermotherapy (Schmidt et al., 2004; Zea et al., 2015). Cryotherapy, the method of pathogen elimination from cryopreserved propagules becomes also one alternative advancement to control microbial contaminants in long-term preserved plant materials (Kaczmarczyk et al., 2011).

\section{Importance of microbial contaminants}

No cell culture problem is as universal as that of culture loss due to contamination (Ryan, 2008). Microbial hazards cause drastic economic losses in the plant tissue culture industries (Leelavanthy and Sankar, 2016) (Figure 2 and 3). Likewise, microbial contamination is now becoming an increasing threat to the consumption of fresh fruits and vegetables in today's world (Balali et al., 2020). By considering the significance of microbes at various pathways in agricultural production, processing and storage, now scientists are advanced to implement high-throughput sequencing (HTS) for fungal and bacterial diagnosis at various stages. Hence, metagenomics approaches are underway for the detection and surveillance of emerging and recurrent plant pathogens that poses a critical threat on agriculture and its constituent produces (Piombo et al., 2021).

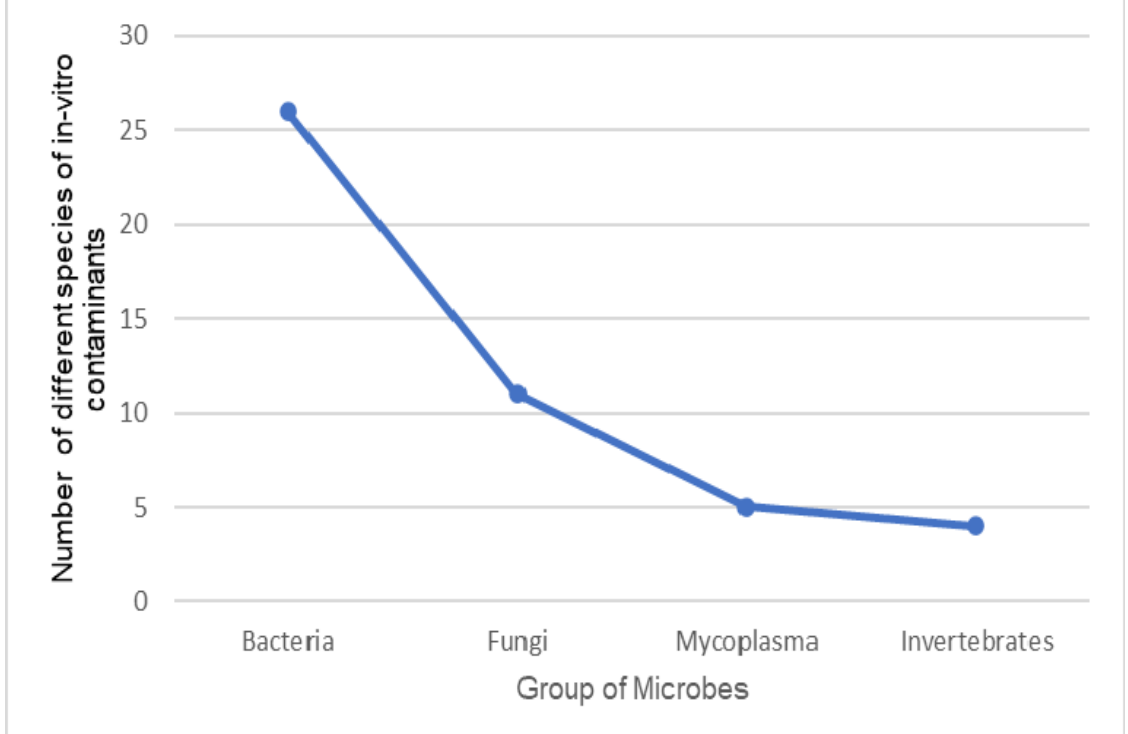

Figure 2: Groups of microbial species frequently reported as contaminating in vitro cultures. 


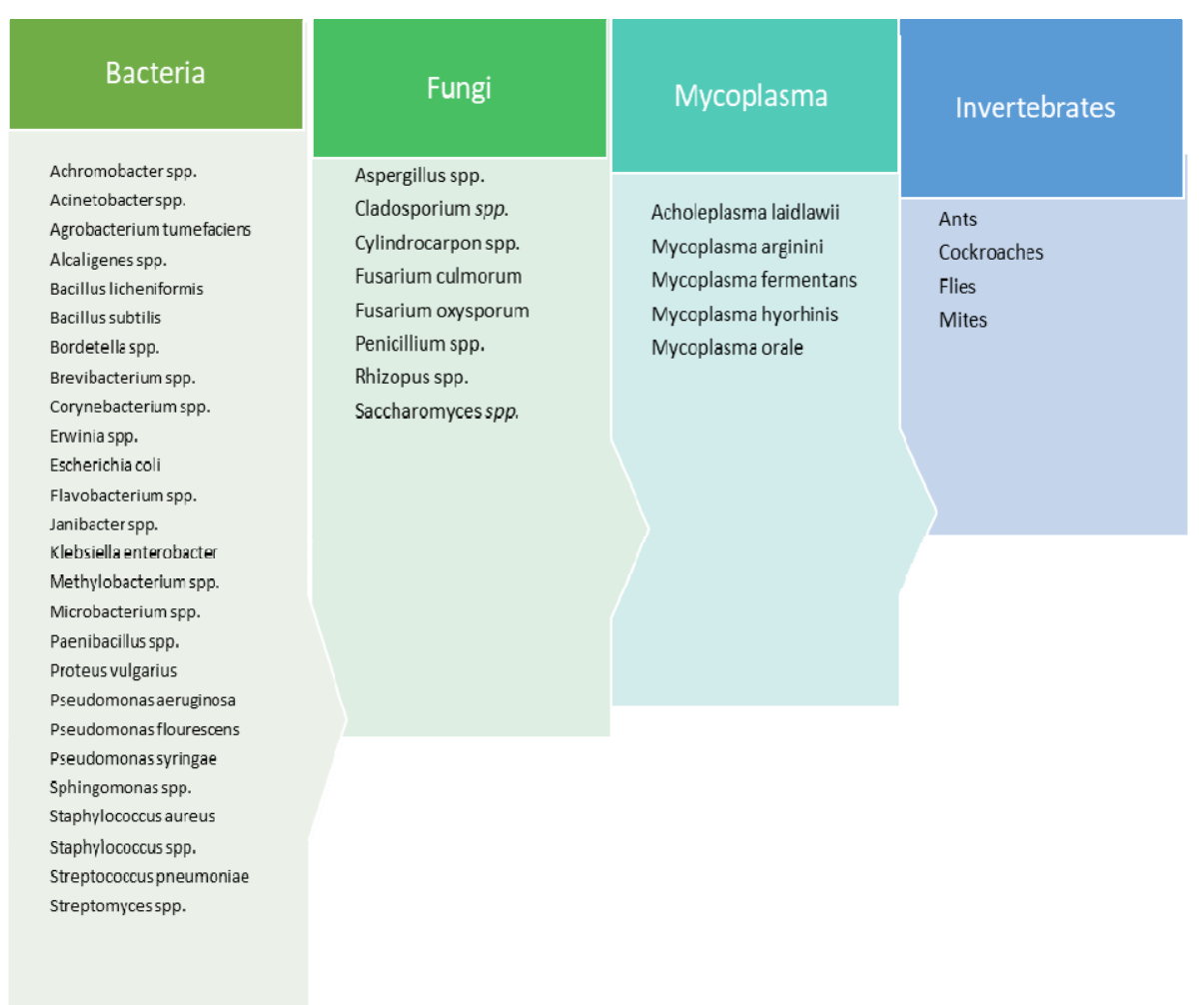

Figure 3: Representative microbial contaminants commonly isolated, characterized and identified at different plant tissue culture laboratories

\section{Types of Contamination}

Tissue culture contamination is categorized into two groups: Chemical contamination and Biological contamination.

\subsection{Chemical contamination}

Chemical contamination occurs due to the presence of any non-living components that negatively affect the growth of culture plants (Ryan, 2008). The sources and types of chemical contamination could be media, serum, endotoxins, storage vessels, fluorescent lights, incubators, waters, that results undesirable effects on culture system.

Media: The cell culture media contains nutrients, reagents, and water which are the major sources of contamination.

Serum and Endotoxin: Serum is a nutrient boost for cell cultures. It contains proteins, hormone, and some growth factors which stimulate tissue growth. However, a variation in the concentration of the hormones and growth factors can be toxic to the cell cultures. Endotoxin is a byproduct of Gram-negative bacteria and found in water, sera, or other culture components. It can be quantified by Limulus Amebocyte Lysate assay (Ryan, 2008).

Plastic tubing and storage vessels: Chemical residue (detergents or disinfectants) in the uncleaned storage vessel leach into media when it is transferred to the vessels. Moreover, plasticizers can also affect the culture growth. Fluorescent light also can photoactivate some media components, such as riboflavin and tryptophan, that release hydrogen peroxide and free radicals that are toxic to the cells (Odutayo et al., 2007).

\subsection{Biological contamination}

Biological contamination is caused due to the presence of living organisms in the culture. Such organisms include easily identifiable bacteria, yeast, and molds or hard to detect viruses, protozoa, and mycoplasmas (Ryan,2008). The sources of microbial contamination in plant tissue culture are complex and needs comprehensive management strategy. Sources of microbes that contaminate our tissue culture laboratory might be from walls, tables, human skins, indoor air, hand gloves, other non-sterilized working instruments other than living entities (Odutayo et al., 2007).

Bacteria, yeast, and molds are ubiquitous in nature. So, they can easily sneak in, colonize, and flourish into the cell cultures. Antibiotics are used to avoid the culture of bacteria; however, some resistant strains can still grow into it (Mbah and Wakil, 2012). There are certain slow-growing very small or intracellular bacteria that are difficult to get noticed during routine checks of the cultures. They can cause serious harm to multiple cultures 
(Figure 4).

Virus, protozoa, and mycoplasma being intracellular in nature are difficult to get identified. They not only destroy the whole cell and tissue culture but they also pose potential hazards to human health (Raaska, 2007; Wirtanen and Salo, 2007).

\section{Consequences of tissue culture contamination}

Microbial contamination is one of the major problems of in-vitro plant culture that directly affects the cost of production and preservation of valuable explants (Liang et al., 2019). The consequences of contamination by microbes are too many and to mention some, losses of time, money, effort and energy. Moreover, it leads to obtain inaccurate experimental results leading to false conclusion by researcher. Loss of valuable products (Figures 5) and adverse effect on the culture (Figure 4) are the major drawbacks of tissue culture contamination by microbes.

On the same fashion to that of in vitro cultures, various bacterial micro-organisms like Bacillus cereus, Staphylococcus aureus, Mycobacterium spp., Escherichia coli etc. have been found to produce biofilms on surfaces of foods and adversely affect the food processing industries at various stages of harvesting, processing and storage (Wirtanen and Salo, 2007). Moreover, micro- organisms reduce the quality of end product by inducing or releasing toxins which are harmful for human health (Raaska, 2007). Micro-arthropods were a serious source of contamination in tissue culture and many laboratory managers admitted that mites can be responsible for severe losses (Pype et al., 1997). This could be because the Micro-arthropod contamination is often accompanied by bacterial contamination. On the other study by (Biswas et al., 2011) causes, concerns, consequences and control mechanisms of microbial contaminants in meat were systematically reviewed and Campylobacter, Staphylococcus aureus, Escherichia coli, Listeria monocytogenes, Clostridium perfringens, Bacillus cereus, and others were reported as bacterial pathogens identified from illness associated with beef products.

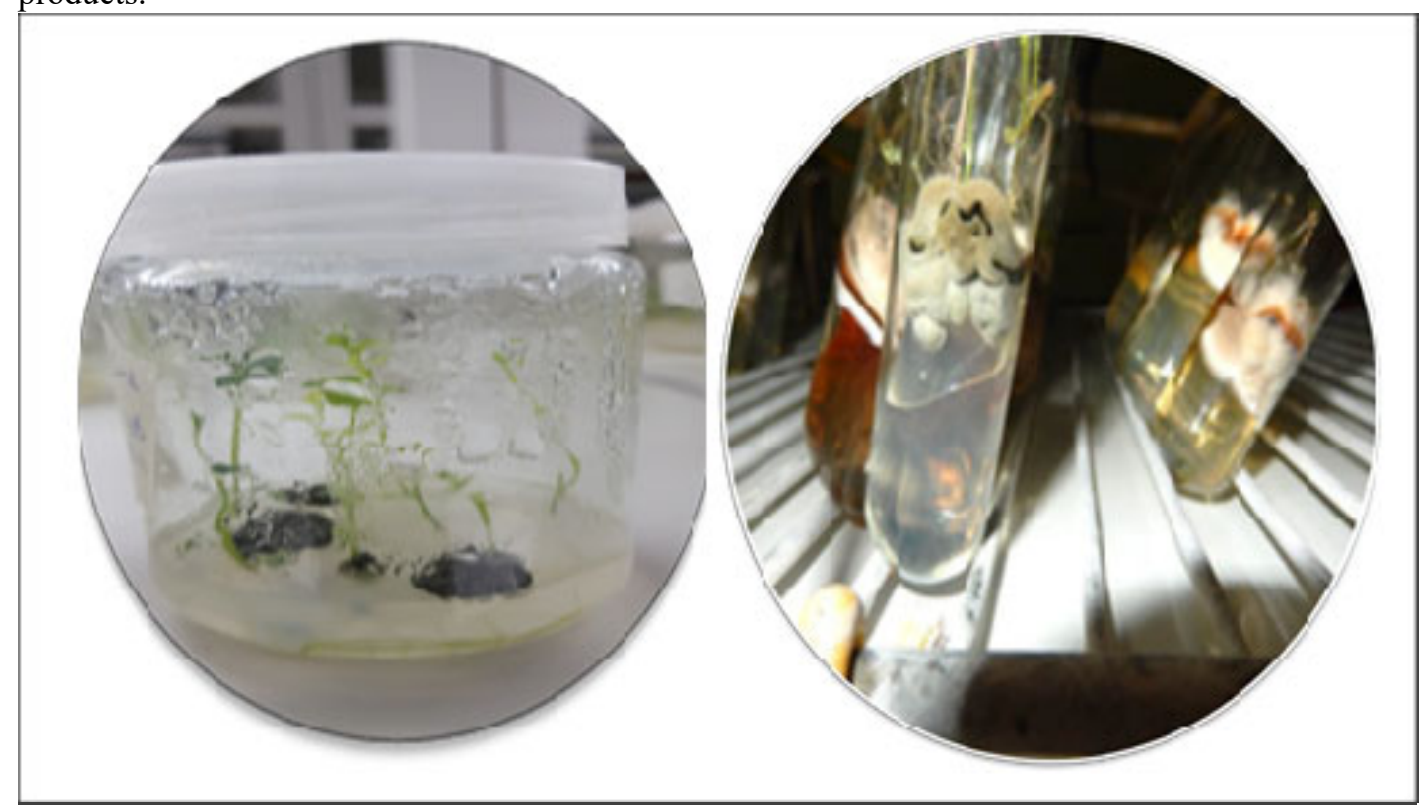

Figure 4: Potato plantlets contaminated by microbes at Holetta Agricultural Research Centre (Photo: (C) Authors)

Percent of in vitro plantlets under potato tissue culture at Holetta Research Centre for 13 months (Figure 5) showed 0 to $90.3 \%$ culture loss (Tessema, 2021, personal communication).

Contamination in culture plantlets may have been reduced to $10 \%$ or even nil in some cultivars due to thorough fumigation of corridors, working rooms, transfer and growth rooms, and the enforcement of strict sanitation rules during sub-culturing (Figure 5). 


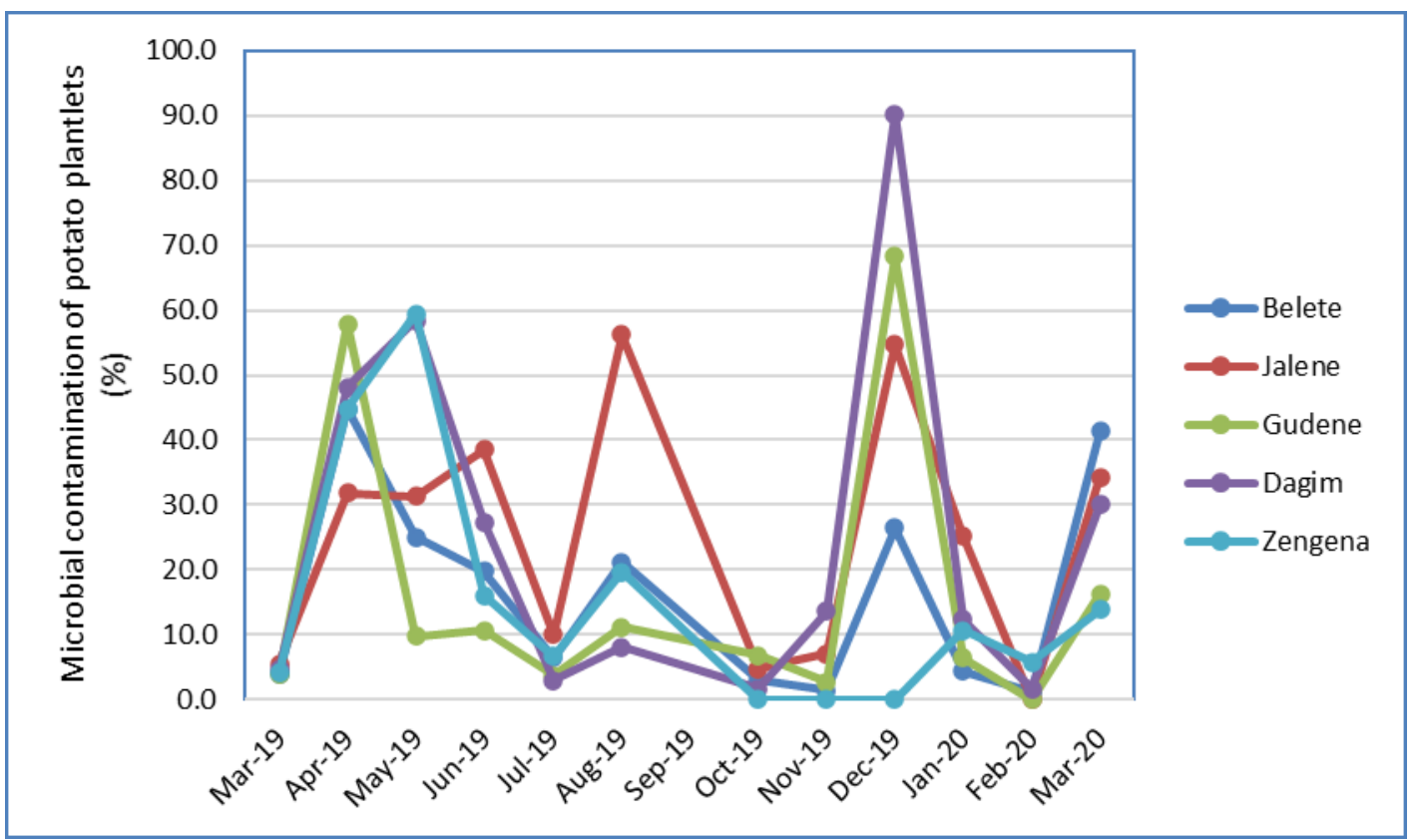

Figure 5: Loss (\%) of potato in vitro plantlets due to tissue culture microbial contamination at Holetta Research Centre, Ethiopia.

\section{Contamination Control Methods}

The current state of science offers a variety of solutions to the microbial contamination issue. To prevent the depletion of numerous resources allocated in the tissue culture, it is critical to reduce the possibility of contamination. Fumigation was justified and recommended as one of effective contamination control mechanism under plant cell culture laboratories (Varghese and Joy, 20160). Different control methods have been reported by different scholars for the advancement of plant tissue culture (Table 1). Although restricted surface sterilization procedures are implemented under plant tissue culture, some bacterial species sourced from explants of the mother plant can survive and contaminate in vitro plantlets (Eziashi et al., 2014).

Table 1: List of some contamination control methods employed for different crops

\begin{tabular}{|c|c|c|c|c|}
\hline $\begin{array}{l}\text { Control methods } \\
\text { employed }\end{array}$ & Plants studied & Contaminants & Reference & Remark \\
\hline Surface sterilization & $\begin{array}{l}\text { Solanecio } \\
\text { biafrae }\end{array}$ & Microbes & $\begin{array}{l}\text { Oluwakemi et } \\
\text { al., } 2018\end{array}$ & $40-100 \%$ clean culture was generated \\
\hline Agar embedding & Moss & Bacteria & $\begin{array}{l}\text { Carey et al., } \\
2015\end{array}$ & $\begin{array}{l}\text { New protocol to control bacterial } \\
\text { contamination for moss culture was developed }\end{array}$ \\
\hline Fumigation & Pineapple & $\begin{array}{l}\text { Bacterial and } \\
\text { fungal spp. }\end{array}$ & $\begin{array}{l}\text { Varghese and } \\
\text { Joy, } 2016\end{array}$ & Effective contamination control \\
\hline $\begin{array}{l}\text { Combination of } \\
\text { morphological methods } \\
\text { and partial } 16 \mathrm{~S} \text { rDNA } \\
\text { sequencing }\end{array}$ & Sweet potato & Bacterial spp. & $\begin{array}{l}\text { Izarra et al., } \\
2020\end{array}$ & Latent bacterial infections were cleaned \\
\hline $\begin{array}{l}\text { Chemotherapeutic } \\
\text { substances }\end{array}$ & $\begin{array}{l}\text { Lilium } \\
\text { candidum } \mathrm{L} .\end{array}$ & Fungal spp. & $\begin{array}{l}\text { Altan et al., } \\
2010\end{array}$ & $\begin{array}{l}\text { Effective treatment against fungal } \\
\text { contamination was determined }\end{array}$ \\
\hline Antibiotics & $\begin{array}{l}\text { Solanum } \\
\text { tuberosum L. }\end{array}$ & Bacterial spp. & $\begin{array}{l}\text { Gubisova and } \\
\text { Gubis, } 2019\end{array}$ & $\begin{array}{l}\text { The efficiency of different } \\
\text { antibiotics at various concentration levels were } \\
\text { evaluated }\end{array}$ \\
\hline $\begin{array}{l}\text { Screening of antibiotics } \\
\text { and sterilizing agents }\end{array}$ & Oil palm & Bacterial spp. & $\begin{array}{l}\text { Eziashi et al., } \\
2014\end{array}$ & $\begin{array}{l}45-90 \% \text { bacterial growth by antibiotics and } \\
10 \% \text { growth inhibition by sterilization was } \\
\text { confirmed. }\end{array}$ \\
\hline $\begin{array}{l}\text { Osmotic } \quad \text { stress } \\
\text { induction }\end{array}$ & Banana & Microbes & $\begin{array}{l}\text { Sinha and } \\
\text { Deka, } 2016\end{array}$ & Contamination was reduced by $40 \%$ \\
\hline Surface sterilization & $\begin{array}{l}\text { Callophylum } \\
\text { inophyllum }\end{array}$ & $\begin{array}{l}\text { Fungi and } \\
\text { bacteria }\end{array}$ & $\begin{array}{l}\text { Putri et al., } \\
2019\end{array}$ & $\begin{array}{l}\text { Successful sterilization and reduced } \\
\text { contamination of } C \text {. inophyllum explant from } \\
\text { field }\end{array}$ \\
\hline
\end{tabular}




\subsection{Antibiotics}

There are certain basic requirements for an antibiotic usage. Although a few antibiotics are heat or light stable, most should be considered as labile, and all preparations should be refrigerated until needed for immediate use by laboratory operators. Bacterial susceptibility to eight different antibiotics (kanamycin, streptomycin, ampicillin, cefotaxime, penicillin, cefazolin, tetracycline, and carbenicillin) was tested using a modified leaf disc diffusion method (Liang et al., 2019). The results from their experiment showed that tetracycline was most effective for inhibiting bacterial growth followed by cefotaxime, carbenicillin, kanamycin, and streptomycin. Whereas ampicillin, penicillin, and cefazolin did not inhibit bacterial growth.

Seven antibiotics (Gentamycin, Ampicillin, Streptomycin, Rifampicin, Tetracycline, Cefotaxime and Penicillin) were evaluated for their potential inhibition of bacterial species in oil palm tissue culture and the result shown that Gentamycin and Ampicillin best inhibited the growth of Mycelia with 90\% suppression. The other antibiotics (Streptomycin, Rifampicin, Tetracycline, Cefotaxime and Penicillin) inhibited the growth of Mycelia 80, 80, 60,55, and 45\%, respectively (Eziashi et al., 2014).

Among different antibiotics unified with potato shoot culture media, Chloramphenicol at a dose of $20 \mathrm{mg} / \mathrm{L}$ had a strong inhibitory effect on potato shoot regeneration, growth, and rotting, suggesting that different antibiotic concentrations have negative or positive effects on potato in vitro culture (Gubisova and Gubis, 2019). The most significant aspect considered during addition of antibiotics in plant growth media is that optimizing the precise concentration for individual plants to reduce inhibitory effect of the antibiotics to plants because the tolerance of explants to antibiotics or other additives in culture media is species or genotype specific (Eziashi et al., 2014). This is an evidence that despite their successful application for the control of microbes, antibiotics can be phytotoxic and have different effects on plant embryogenesis regenerative ability unless the appropriate procedure and recommended concentration are used by the operator (Cornu and Michael, 1987).

\subsection{Surface sterilization and restricted sanitation procedures}

Implementation of surface sterilization and following restricted laboratory sanitation procedures could reduce the chance of culture contamination, in turn saves our precious plant products with low cost incurred. The rate of microbial contamination in the plant tissue culture is probably aggravated by improper handling and non- sterile environments (Leelavanthy and Sankar, 2016). Most of in vitro contaminants in plant tissue culture arises from several sources, but could be checked by using several available surface sterilant and reduced by maintaining aseptic conditions (Ray and Ali, 2016). Plant surfaces are habitats for many microorganisms that are opportunists to enter in the plant tissues through wounds or natural openings during culturing even under aseptic environments (Eziashi et al., 2014).

Surface sterilization of plant materials is a very problematic step in establishing plant tissue culture protocol (Carey et al., 2015). Some culture contaminant bacteria, once they got contaminated with the hardy spores of bacteria like Bacillus spp. the spores could survive for a long period of time, means the adulterated alcohol could serve as a source of inoculum causing subsequent spread of an unanticipated contamination to the in vitro culture (Thomas, 2012; Thomas and Aswath, 2014). According to Eziashi et al., (2014) surface sterilization of sterile distilled water showed poor contaminant control $(10 \%)$ of bacteria in potato tissue culture compared to antibiotics (45-90\%). However, sterilization is the most possible technique to applied by any plant tissue culture technician and the sterilizing agents like distilled water, ethanol and Clorox or other detergents are relatively cheaper and accessible to any plant tissue culture.

Successful sterilization of $C$. inophyllum explants with minimal microbe contamination was reported for the first time with low rates of mortality of rooted plantlets during acclimatization (Putri et al., 2019). However, Mineykina et al. (2020) reported that a standard sterilization procedure was sufficient for effective elimination of bacteria and ensuring normal microspore development in Brassica species, when the amount of initial bacterial infection at the surface of plant material was small (e.g., in the young plants grown in artificial climate chambers). Generally, to prevent microbial contamination and save in vitro cultures, the technician working under plant tissue culture laboratory should follow the precautionary steps during all the entire steps of micropropagation.

1. Keep the laboratory clean

2. Wear gloves and laboratory coat

3. Routinely monitor for contamination

4. Use high-grade chemicals

5. Sterilize lab equipment

6. Avoid cell tissue exposure to non-sterilized surroundings

7. Regularly check the cultured in vitro

\section{Summary and Conclusion}

Now a days, micropropagation, is gaining importance for large scale propagation due to its capability in raising 
huge number of true to type propagules in a limited space in very short period of time without any seasonal limitations. Applications of plant tissue culture for micropropagation, germplasm preservation, soma clonal variation, haploid and diploid production and in vitro hybridization provide an opportunity for plant scientists and researchers worldwide engaged in agriculture. However, microbes pose serious problems by contaminating the precious plant materials to be used for food, feed, raw industry material and has multipurpose values.

Knowing the source of microbial contamination is crucial step for minimizing the risk of invitro cultures. Detection of microbial contamination must be conducted as early as possible before huge losses of limited resources (time, money, labour effort) and to save our precious cultures under laboratory. Although absolute prevention of microbial contamination is impossible, the laboratory manager can take numerous measures to prevent infection by ensuring that he/she is working in a sterile environment and using proper aseptic techniques. Generally, thoughtful application of aseptic laboratory procedures by every technician or manager under any cell or tissue culture laboratory could save the most precious plant cultures, time, production cost and enable to reduce the threat posed by contaminants in invitro cultures everywhere in the globe.

\section{Author Contributions}

LT wrote the manuscript to its final version; ES and ZM read and approved the final version of the manuscript.

\section{Funding}

the authors did not receive any external fund for this work

\section{Conflict of interest}

The authors declare no conflict of interest.

\section{Data Availability}

All data used for this article have been included in the article

\section{Reference}

Aboshama HM, Atwa, MM. 2019. Anther Culture in Potato (Solanum tuberosum L.) in vitro. Journal of Plant Biochemistry and Physiology, 7, 244. https://doi.org/10.35248/2329-9029.19.7.244.

Al-Taleb MM, Hassawi DS, Abu-Romman SM. 2011. Production of Virus Free Potato Plants Using Meristem Culture from Cultivars Grown under Jordanian Environment. American-Eurasian Journal of Agriculture and Environmental Sciences, 11(4): 467-472.

Altan F, Burun B, Sahin N. 2010. Fungal contaminants observed during micropropagation of Lilium candidum L. and the effect of chemotheraptic substances applied after sterilization. African Journal of Biotechnology, 9 (7): 991-995.

Asakaviciute R, Clement C, Razukas A. 2007. The genetic aspect in anther culture of Luthuanian potato (Solanum tuberosum L.) cultivars. Biologija, 18(1):19-22.

Azad Md.AK, Khatun Z, El-Jaoul Eaton T, Hossen Md.I, Haque Md.K, Soren EB. 2020. Generation of Virus Free Potato Plantlets through Meristem Culture and Their Field Evaluation. American Journal of Plant Sciences, 11:1827-1846. https://doi.org/10.4236/ajps.2020.1111131.

Bajaj YPS. 1987. Cryopreservation of Potato Germplasm. In: Bajaj YPS (ed.) Potato. Biotechnology in Agriculture and Forestry, vol. 3. Springer, Berlin, Heidelberg. https://doi.org/10.1007/978-3-642-7277333.

Balali GI, DekugmenYar D, Afua Dela VG, Adjei-Kusi P. 2020. Microbial Contamination, an Increasing Threat to the Consumption of Fresh fruits and Vegetables in today's world. International Journal of Microbiology,2020, 3029295: 1-13. https://doi.org/10.1155/2020/3029295.

Biswas AK, Kondaiah N, Anjaneyulu ASR, Mandal PK. 2011. Causes, Concerns, Consequences and Control of Microbial Contaminants in Meat-A Review. International Journal of Meat Science, 1(1):27-35. https://doi.org/10.3923/ijmeat.2011.27.35.

Bonierbale MW, Amoros WR, Salas E, de Jong W. 2020. Potato Breeding. In: Campos and Ortiz (eds). The Potato crop. Pp. 163-217.

Bruce MA, Shoup Rupp JL. 2019. Agrobacterium-mediated Transformation of Solanum tuberosum L., Potato. In: Kumar S, Barone P and Smith M. (eds) Transgenic Plants. Methods in Molecular Biology, 1864. Human Press, New York, NY. https://doi.org/10.1007/978-1-4939-8778-8_15.

Bryan JE. 1983.The Importance of Planting Material in Root and Tuber Crops Production. In: Cock JH. (ed.). Global Workshop on Root and Tuber Crops Propagation. Proceedings of a Regional Workshop held in Cali, Colombia, 13-16 September, 1983. ISBN: 84-89206-53-8. Pp 3-5.

Budd S. 2016. Best practices in cryopreservation. Cell Biology Systems, ATCC, Webinar presentation ppt, www.attc.org/webinars. 
Carey SB, Payton AC, McDaniel SF. 2015. A mothed for eliminating bacterial contamination from in vitro Moss cultures, Protocol note. Applications in plant sciences, 3(1). https://doi.org/10.3732/apps.1400086.

Castillo A, Gaiero P, Lopez Carro B, Vilaro F. 2016. Genetic Embryogenic Response in Wild Diploid Solanum Species and Implications for Genome Sequencing Projects and Breeding. Plant Tissue Culture and Biotechnology, 26(2):159-173.

Chetty VJ, Naravaez-Vasquez J, Orozco-Cardenas ML. 2015. Potato (Solanum tuberosum L.). Methods in Molecular Biology,1224:85-96. http://doi.org/10.1007/978-1-4939-1658-0_8.PMID:25416251.

Cingel A, Vinterhalter B, Vinterhalter D, Calic-Dragosavac D, Smigocki A, Ninkovic S. 2010. Agrobacteriummediated transformation of two Serbian potato cultivars (Solanum tuberosum L. cv. Dragacevka and cv. Jelica). African Journal of Biotechnology, 9(30):4644-4650.

CIP, 2021a. Advanced potato germplasm collection. Available at https://cipotato.org/genebankcip/process/breeding_lines/[Accessed on 17 $7^{\text {th }}$ March 2021).

CIP, 2021b. Invitro conservation. Available at https://cipotato.org/genebankcip/process/invitro/active collection/ [ accessed on $17^{\text {th }}$ March 2021).

Conner AJ, Williams MK, Gardner RC, Deroles SC, Shaw ML, Lancaster JE. 1992. Agrobacterium-mediated transformation of New Zealand potato cultivars. New Zealand Journal of Crop and Horticultural Science, 19 (1):1-8. http://doi.org/10.1080/01140671.10418098.

Cornu D, Michael M.F. 1987. Bacterial contamination in shoot cultures of Prunus anum and phytotoxicity of antibiotics. Acta Horticulturea, 212:83-86.

Cruz-Cruz C.A, Gonzalez-Arnao M.T, Engelmann F. 2013. Biotechnology and Conservation of Plant Biodiversity. Resources, 2:73-95. https: doi.org/10.3390/resources2020073.

Ellis D, Salas A, Chavez O, Gomez R, Anglin N. 2020. Ex Situ Conservation of Potato [Solanum Section Petota (Solanaceae)] Genetic Resources in Genebanks. In: Campos H and Ortiz O. (eds) The Potato Crop. Springer, Cham. https://doi.org/10.1007/978-3-030-28683-5_4

Espinosa-Leal, CA, Puente-Garza CA, Garcia-Lara S. 2018. In-vitro plant tissue culture: means for production of biological active compounds. Planta, 248:1-18. https://doi.ord.10.1007.s00425-018-2910-1.

Eziashi EI, Asemota O, Okwuagwu CO, Eke CR, Chidi NI, Oruade-Dimaro EA. 2014. Screening sterilizing agents and antibiotics for the elimination of bacterial contaminants from oil palm explants for plant tissue culture. European Journal of Experimental Biology, 4(4):111-115.

FAO. 2017. The Future of food and agriculture-Trends and challenges. Food and Agriculture Organization of The United Nations, Rome, Italy. Pp. 180. ISBN: 978-92-5-109551-5.

FAO/IAEA. 2018. Manual on mutation Breeding-Third edition. Spencer-Lopes, M.M., Forster, B.P. and Jankuloski, L. (eds.), Food and Agriculture Organizations of the United Nations. Rome, Italy.301 pp.

Germana MA. 2011. Anther culture for haploid and double haploid production. Plant cell, tissue and organ, 104:283-300. https://doi.org/10.1007/s11240-010-9852-z

Ghislain M, Douches D.S. 2020. The Genes and Genomes of the Potato. In: Campos H and Ortiz O. (eds). The Potato Crop. Pp. 139-162. Springer, Cham. https://doi.org/10.1007/978-3-030-28683-5 5.

Gubisova M, Gubis J. 2019. Growth of potato shoot cultures on media with antibiotics for elimination of bacterial contamination. Agriculture (Polnohospodarstvo), 65(3):99-106. https://doi.org/10.2478/agri-20190010 .

Hijmans RJ, Spooner DM. 2001. Geographic distribution of wild potato species. American Journal of Botany, 88(11):2101-2112. PMID:21669641.

IAEA, 2004. Low-cost options for tissue culture technology in developing countries. In: Proceedings of a Technical Meeting Organized by the joint FAO/IAEA division of Nuclear techniques in Food and Agriculture and held in Vienna, 26-30 August 2002, Vienna, Austria: International Atomic Energy Agency. ISBN: 92-0-115903-X.

Izarra ML, Panta AL, Maza CR, Zea BC, Cruzado J, Gutarra LR, Rivera CR, Ellis D, Kreuze JF. 2020. Identification and control of Latent Bacteria in in-vitro Cultures of Sweet Potato [Ipomoea batatas (L.) Lam]. Frontires in Plant Sciences, 11: 903.doi:3389/fpls.202000903.

Jansky S.H, Charkowski A.O, Douches D.S, Gusmini G, Richael C, Bethke P.C, Spooner D.M, Novy R.G, De Jong H, De Jong W.S, Bamberg J.B, Thompson B.B, Holm D.G, Brown C.R, Haynes K. G, Sathuvalli V.R, Veilleux R.E, Miller J. Creighton, Bradeen J.M, Jiang J.M. 2016. Reinventing Potato as Diploid Inbred Line-Based Crop. Crop science, 56:1-11. https://doi.org/10.2135/cropsci2015.12.0740.

Johnson KA. 2002. Invitro Conservation Including Rare and Endangered Plants, Heritage Plants and Important Agricultural Plants. In: Taji A. and Williams R. (eds). The importance of Plant Tissue Culture and Biotechnology in Plant Sciences. Pp. 79-90. ISBN: 186389781 X

Kaczmarczyk A, Rokka VM, Keller ERJ. 2011. Potato shoot tip cryopreservation. Potato Research, 54:45-79. https://doi.org/10.1007/s11540-010-9169-7.

Kidus T, Teka Z. 2020. Isolation, Characterization and Identification of Contaminant Bacteria from Sugarcane 
(Saccharum officinarum L.) in vitro Culture in Tigray Biotechnology Centre, Mekkelle, Ethiopia. Journal of Bacteriology and Parasitology, 11: 372. hpps://doi.org/10.35248/2155-9597.20.11.372.

Lawrence RH. JR. 1981. In-vitro plant cloning systems. Environmental and Experimental Botany, 21(3-4): 289300.

Leelavanthy S, Sankar PD. 2016. Curbing the Menace of Contamination in Plant Tissue Culture. Journal of Pure and Applied Microbiology, 10(3):2145-2152.

Leifert C, Cassells AC. 2001. Microbial Hazards in Plant Tissue and Cell Cultures. In Vitro Cellular and Developmental Biology-Plant, 37(2): 133-138. https://doi.org/10.1079/IVP2000129.

Liang C, Wu R, Han Y, Wan T, Cai Y. 2019. Optimizing Suitable Antibiotics for Bacterium Control in Micropropagation of Cherry Rootstock Using a Modified Leaf Disk Diffusion Method and E Test. Plants,8:66. https://doi.org/10.3390/plants8030066.

Lincoln K.L, Gabridge M.G. 1998. Cell culture contamination: sources, consequences, prevention and elimination. In: Methods in cell biology, 56:49-65. Academic press, New York.

Loyola-Vargas VM, Ochoa-Alejo N. 2018. An Introduction to Plant Tissue Culture: Advances and Perspectives. In: Loyola-Vargas VM, Ochoa-Alejo N. (eds) Plant Cell Culture Protocols. Methods in Molecular Biology, 1815. Humana Press, New York, NY. https://doi.org/10.1007/978-1-4939-859441.

Mather J, Roberts E. 1998. Contamination: How to avoid it, recognize it, and ret rid of it. In: Introduction to cell and tissue culture: Theory and Technique. Pp. 99-109.

Mbah EI, Wakil SM. 2012. Elimination of bacteria from in vitro Yam tissue cultures using antibiotics. Journal of Plant Pathology, 94:53-58.

Melchers G, Sacristan MD, Holder AA. 1978. Somaclonal hybrid plants of potato and tomato regenerated from fused protoplasts. Carlsb Research Communication, 43:203 218. https://doi.org/10.1007/B F02906548.

Milczarek D, Przetakiewicz A, Kaminski P, Flis B. 2014. Early selection of potato clones with the H1 resiatance genes-the relation of nematode resistance to quality characteristics. Czech Journal of Genetics and Plant Breeding, 50:278-284.

Millam S. 2007. Developments in Transgenic Biology and the Genetic Engineering of Useful Traits. In: Vreugdenhil D. (ed.). Potato Biology and Biotechnology: Advances and Perspectives. Pp.669-686. Elsevier, The Boulevard, Langford, Kidlington,Oxford OX5 1GB, UK.

Mineykina A, Shumilina D, bondareva L, Soldatenko A, Domblides E. 2020. Effect of Beta-Lactam Antibiotics on Microspore Embryogenesis in Brassica Species. Plants, 9:489. doi.org/10.3390/plants9040489.

Odutayo OI, Oso RT, Akinyemi BO, Amusa NA. 2004. Microbial contaminants of Hibiscus cannabinus and Telfaria occidentalis tissues. African Journal of Biotechnology,3(9):473-476.

Odutayo OI, Amusa NA, Okutade OO, Ogunsanwo YR. 2007. Sources of microbial contamination in tissue culture laboratories in southwestern Nigeria. African Journal of Agricultural Research, 2(3):067-072.

Oluwakemi AB, Edward BE, Olawole O. 2018. Establishing surface sterilization protocol for nodal culture of Solanecio biafrae. IOP Conference Series: Earth and Environmental Sciences, 210012007. doi:10.1088/1 gpd755-1315/210/1/012007.

Ortiz R, Mihovilovich E. 2020. Genetics and Cytogenetics of the Potato. In: Campos and Ortiz (eds). The Potato crop. Springer, Cham. Pp. 219-247.

Peloquin SJ, Gabert AC, Ortiz R. 1996. Nature of 'Pollinator' Effect in Potato (Solanum tuberosum L.) Haploid Production. Annals of Botany, 77:539-542.

Piombo E, Abdelfattah A, Droby S, Wisniewski M, Spadaro D, Schena L. 2021. Metagenomics Approaches for the Detection and Survillance of Emerging and Recurrent Plant Pathogens. Microorganisms, 9:188. https://doi.org/10.3390/microorganisms9010188.

Plumier G. 2019. Improvement of the Cryopreservation Protocol of Cassava (Manihot esculenta) by Droplet Vitrification: The Influence of the Accession, Loading Solution, Meristem Position, and Preculture. KU Leuven.

Putri AI, Leksono B, Winfyarini E, Hasnah TM. 2019. Tissue culture sterilization of callophylum inophyllum: Renewable energy resources. AIP Conference Proceedings 2020,030004(2019). https://doi.org/10.1063/1.5115608.

Pype J, Eveaert K, Debergh P. 1997.contamination by Micro-arthropods in plant tissue cultures. In: Cassells A.C (ed.) Pathogen and Microbial Contamination Management in Micropropagation. Kluwer Academic Publishers. Pp.259-266.

Raaska L. 2007. Microbial ecology in manufacturing paper-based packaging materials for use in food industry. Pp. 16-19. In: Wirtanen and Salo (eds). Microbial contaminants and their contamination routes in food industry. First open seminar arranged by Safoodnet-Food safety and hygiene networking within new member states and associated candidate countries; EP6-022808-2006, Espoo, Finland, January 22-13, 2007. 
ISBN: 978-951-38-6320-3.

Ray SS, Ali N. 2016. Biotic Contamination and Possible Ways of Sterilization: A Review with Reference to Bamboo Micropropagation. Agriculture, Agrobusiness and Biotechnology, Brazilian Archives of Biology and Technology, 59: e160485 (1-12). https://dx.doi.org/10.1590/1678-4324-2016160485

Rayan J. 2008. Understanding and managing cell culture contamination. Technical bulletin. 24pp. Corning incorporated life sciences, 900 Chelmsford Street, Lowell, MA 01851, New York.

Schmdit J, Wilhem E, Savangikar VA. 2004. Disease detection and elimination. Low-cost options for tissue culture technology in developing countries. In: Proceedings of a Technical Meeting organized by the joint FAO/IAEA division of Nuclear techniques in Food and Agriculture and held in Vienna, 26-30 August 2002 (pp. 55-61). Vienna, Austria: International Atomic Energy Agency. ISBN: 92-0-115903-X.

Scortichini M, Chiariotti A. 1987. Bacterial contaminations in plant tissue culture: preliminary studies on techniques of detection and effects of various antibiotic compounds. Advances in Horticultural Sciences, 1(2):68-72. Retrieved November 11,2020, from http://www.jstor.org/stable/42881323.

Singh CR. 2018. Review on problems and its remedy in plant tissue culture. Asian journal of biological sciences, 11:165-172.

Sinha SK, Deka AC. 2016. Effect of osmotic stress on in vitro propagation of Musa sp. (Malbhog variety). African Journal of Biotechnology, 15(13):490-496. https://doi.org/10.5897/AJB2015.14446.

Spooner DM, Ghislain M, Simon R, Jansky S.H, Gavrilenko T. 2014. Systematics, diversity, genetics, and evolution of wild and cultivated potatoes. Botany and Revolution, 80:283-383. https://doi.org/10.1007/s12229-014-9146-y.

Stewart J. McD. 1981. In vitro fertilization and embryo rescue. Environmental and Experimental Botany, 21(34):301-315. https://doi.org/10.1016/0098-8472/(81)90040-x.

Tazeb A. 2017. Plant tissue culture techniques as a novel tool in plant breeding: A review. American-Eurasian Journal of Agriculture and Environmental Sciences, 17(2):111-118. https://doi.org/10.5829.idosi.aejaes.2017.111.118

Tegen H, Mohammed W. 2016. The role of Plant Tissue Culture to Supply Disease Free Planting Materials of Horticultural Crops in Ethiopia. Journal of Biology, Agriculture and Healthcare, 6(1):122-129.

Tessema L, Chindi A, Woldegiorgis G, Solomon A, Shunka E, Seid E. 2018. Accelerating seed potato production by using rapid multiplication systems in Ethiopia. Open Science Journal, 3(1):1-9. https://doi.org/10.23954/osjv3i1753.

Tessema L, Seid E, Woldegiorgis G, Sharma K. 2020. Current status of bacterial wilt (Ralstonia solanacearum) disease in major seed potato (Solanum tuberosum L.) growing areas of Ethiopia. Journal of plant Pathology and Microbiology, 11:497. https://doi.org/10.35248/2157-7471.20.11.497.

Tessema L, Dagne Z. 2018. Aeroponics and Sand Hydroponics: Alternative Technologies for Pre-basic Seed Potato Production in Ethiopia. Open agriculture, 3:444-450. https://doi.org/10.1515/opag-2018-0049.

Thomas P. 2012. Long-Term Survival of Bacillus Spores in Alcohol and Identification of 90\% Ethanol as Relatively More Spori/Bacterial. Current Microbiology,64:130-139. https://dx.org/10.1007/s00284-0110040-0.

Thomas P, Aswath C. 2014. Invitro introduction of hardy alcohol resistant Bacillus spp. through aseptically grown watermelon seedlings. Advances in Microbiology, 4:504-510. https://dx.doi.org/10.2436/aim.2014.49056.

Tiwari, JK, Devi S, Ali N, Luthra SK, Kumar V, Bhardwaj V, Singh RK, Chakrabarti SK. 2018. Progress in somatic hybridization in potato during the past 40 years. Plant Cell, Tissue and Organ Culture, 132:225238. https://doi.org/10.1007/s11240-017-1327-z.

Varghese N, Joy PP. 2016. Plant tissue culture contaminants identification and its response to fumigation. Technical report, pp.1-10.

Vollmer R, Villagaray R, Egusquiza V, Panta A, Barkley N, Ellis D. 2016. Genebank: Cryopreservation of potato, V.2. CIP-OP106. 30PP.

Wang D, Ran Y. 2000. Improving main agronomic characters of dihaploids with $2 \mathrm{n}$ gametes by means of sexual hybridization and anther culture of potato (Solanum tuberosum).

New Zealand Journal of Crop and Horticultural Sciences, $28: 1-8$. https://doi.org/10.1080/01140671.2000.9514116.

Wilms H, Sleziak N.F, Van der Auweraer M, Brnads M, Verleije M, Hardeman D, Andre E, Panis B. 2020. Development of a fast and user-friendly cryopreservation protocol for sweet potato genetic resources. Scientific Report, 10:14674. https://doi.org/10.1038/s41598-020-70869-3.

Wirtanen G, Salo S. 2007. Biofilm formation in food processes. In: Wirtanen and Salo (eds). Microbial contaminants and their contamination routes in food industry. First open seminar arranged by SafoodnetFood safety and hygiene networking within new member states and associated candidate countries; EP6- 
022808-2006, Espoo, Finland, January 22-13, 2007. ISBN: 978-951-38-6320-3. Pp. 10-15.

Yadav MK, Kumar A, Priya P, Sharma S. 2019. Plant tissue culture technology to improve crop species-A comprehensive approach. Acta Scientific Agriculture, 3(2):76-80.

Zea B, Ynga A, Ruiz M, Cruzado J, Panta A, Barkley NA, Ellis D. 2015. Genbank: Pathogen elimination of Potato. CIP-PO017. V.19. 